The Bangladesh V eterinarian (2016) 33(2) : 39 - 50

\title{
The clinicopathology of foot and mouth disease and molecular epidemiology of the viruses circulated in cattle of Pabna district, Bangladesh
}

\author{
MR Nazneen, MS Islam, UK Rimaㄹ, D Biswas, R Afroze, MM Hossain and \\ MAHNA Khan* \\ Department of Pathology, Faculty of Veterinary Science, Bangladesh Agricultural \\ University, Mymensingh-2202, Bangladesh
}

\begin{abstract}
This study investigated outbreaks of Foot and Mouth Disease (FMD) in cattle in Pabna district, Bangladesh, during August-September 2015. Out of 100 cattle, 45 were infected with FMD virus, of which five young and two adult cattle died and the postmortem changes in internal organs were recorded. Oral tissue samples from infected cattle $(n=20)$ of four Upazillas (Sub-district) of Pabna district were collected for viral RNA extraction and serotype identification using reverse transcriptase polymerase chain reaction (RTPCR). Gross and histopathological changes in oral, pedal and mammary tissues were typical of FMD. Characteristics lesion of 'tiger heart disease' was seen in heart muscle of young and adult cattle. There was thickening of interlobular septum of lungs and characteristics of interstitial pneumonia. The uniplex and multiplex RT-PCR detected FMD viruses (430 bp) and FMD viral serotypes "O" (402 bp) and "A sia 1" (292 bp). Cattle of Sujanagar, Chatmahar and Isshardi Upazillas of Pabna district were infected with FMD viral serotype "O" and responsible for mortality of three young and two adult cattle. FMD viral serotype "Asia 1" causing death of two young cattle at Pabna Sadar. The fragment (485 bp) of Vpl gene of FMD viral serotype "O" sequenced showed mutation in main antigenic sites. The phylogenetic analysis carried out with the Vpl gene of FMD viral serotype "O" showed the viruses belonging to ME-SA topotype. The death of young and adult cattle was probably due to cardiac and/ or respiratory failure. The adapted RTPCR protocol can be used in practice for detecting FMD viruses and its serotyping. Larger samples sizes require investigating to identify existing FMD viral serotypes and topotypes in order to design future preventive strategies. (Bangl. vet. 2016. Vol. 33, No. 2, $39-50$ )
\end{abstract}

\section{Introduction}

Foot and mouth disease (FMD) is a common viral disease of cloven-hoofed animals, causing severe economic loss in Bangladesh (Islam et al., 2011). Typical signs of FMD include fever, vesicular eruption in the mouth, tongue, inter-digital skin and teats (APHIS, 2007; Shanmugam et al., 2015). In Bangladesh, outbreaks of FMD in cattle are common and may be exacerbated by use of ineffective FMD vaccines, lack of routine immunization, introduction of mutant viruses through cattle movement, use of

1Department of Medicine, Surgery and Obstetrics Faculty of Veterinary \& A nimal Science, Hajee Mohammad Danesh Science \& Technology University, Dinajpur, Bangladesh

*Corresponding author:- E-mail: hadi.khan@bau.edu.bd 
vaccines of heterogeneous strains or diverse strains of FMD viruses even within same serotypes. FMD virus (FMDV) has the potential for rapid and extensive spread within and between countries (Alexandersen et al., 2003).

FMDV is a member of the genus A phthovirus family Picornaviridae and is considered to be the most contagious agent infecting farm animals. It can spread rapidly through livestock populations across continents. FMDV is often transmitted through air or direct contact (Gomes et al., 1997). Animals that recover can remain carriers for years (McVicar and Sutmoller, 1976; Salt et al., 1996), may intermittently shed the virus and can cause FMD outbreaks (Brown et al., 1996). Affected animals hardly attain their original production (Rubina et al., 2006). FMD is difficult to control owing to its contagiousness and existence of seven serotypes (A, C, O, A sia 1, SAT 1, SAT 2 and SAT 3), comprising numerous antigenic variants (I slam et al ., 2016; Brown, 2003). Out of seven serotypes of FMD viruses, four (O, A, C and Asia 1) was reported earlier in Bangladesh (Freiberg et al., 1999). Serotype $C$ is no longer prevailing in the world since 1990 (Chowdhury et al., 1996). Studies conducted by Bangladesh Livestock Research Institute (BLRI) revealed that an outbreak of FMD could cause $36 \%$ morbidity in cattle, $23 \%$ in buffaloes and $5 \%$ in goats and sheep and a fatality rate in calves of $51 \%$ (www.blri.gov.bd). A nnual losses due to FMD have been estimated to be US\$10.9 million per year (Islam, 2011).

Diagnosis of FMD is commonly made by observing clinical signs but it is difficult to detect serotypes of virus involved. The diagnosis of viral serotypes is usually made by enzyme-linked immunosorbent assay (ELISA), complement fixation test (CFT), virus neutralization test (Knowles and Samuel, 2003), RT-PCR (Islam et al., 2017a; Pervin et al., 2011). The RT-PCR protocol has been widely used and involves universal primers for the detection of FMDV regardless of serotype (Islam et al ., 2016; Reid et al ., 2003). Multiplex RT-PCR (mRT-PCR) was introduced by Alamdari et al. (2006) and Bao et al. (2008) were in use to identify the serotypes of circulating FMDV. Histopathology of various organs was carried out to reveal the cause of death of young and adult cattle. Following RT-PCR detection of viral serotypes, the VP1 genes were amplified and sequenced to identify the level of mutation in the antigenic sites. The sequence information of VP1 gene was used in phylogenetic analysis and to identify the topotypes of the viruses involved.

\section{M aterials and Methods}

This investigation was carried out in Sujanagar, Chatmahar, Isshardi and Sadar Upazilla of Pabna district, Bangladesh during August and September 2015. A total of 25 cattle from each Upazilla were investigated to know the morbidity and mortality pattern of cattle due to FMD. 20 infected cattle from four Upazillas, five from each were selected to collect oral tissues for FMD viral RNA extraction and detection of viral serotypes. Three infected dead calves and two adult dead cattle were investigated by necropsy and histopathology to assess the lesions. 


\section{Clinicopathological investigations}

Ten cattle in a dairy farm (Sujanagar Upazilla, Pabna) were investigated to assess the infectivity during outbreaks. Rectal temperature was recorded for 7 consecutive days. The oral and pedal lesions and relevant signs were recorded. In acute phase of infection scrapings from oral lesions were collected and snap-frozen for the extraction of viral RNA and RT-PCR detection of viral serotypes (Islam et al., 2016). Three infected calves ( $<$ six months of age) and one adult cow (>one year of age) were found dead, and post-mortem and histopathological investigations were done. Representative tissues from the affected organs were preserved in $10 \%$ buffered neutral formalin, sectioned and stained using haematoxylin and eosin (Luna, 1968).

\section{Extracted FMD viral R NA}

The samples collected from oral lesions $(n=20)$ of acutely infected cattle were snapfrozen for the extraction of viral RNA. Viral RNA from the infected and control tissues (one representative sample from each farm) were extracted using Viral Nucleic Acid Extraction Kit II (Geneaid Biotech Ltd., Taiwan) as per manufacturer's instructions. The high quality RNA was eluted in $30 \mu \mathrm{L}$ of nuclease-free water, the

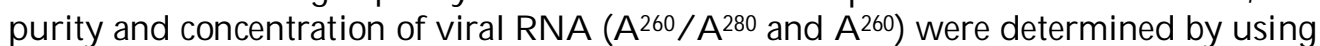
spectrophotometer (Lan et al., 2009). The pure RNA has an approximate $A^{260 /} A^{280}$ ratio above 1.8 in Tris- $\mathrm{HCl}$ buffer and proven pure RNA was used in RT-PCR detection of the viruses.

\section{RT-PCR detection of FM D viruses}

Uniplex and multiplex RT-PCR were used to detect FMD viruses and viral serotypes using published primers (Table 1). The RT-PCR reaction was carried out in $25 \mu \mathrm{L}$ containing $2 x$ Master mix, 70 to 100 ng RNA and 20 pmoL primers in each with the thermal profile stated in Table 2. Five infected samples from each of the farms were tested induding known positive RNA (from repository) to detect the FMD viruses and viral serotypes circulating.

Table 1: Primer sequences used in uniplex and multiplex RT-PCR detection of FMD viruses and viral serotypes respectively

\begin{tabular}{|c|c|c|c|c|c|}
\hline Serotype & $\begin{array}{l}\text { Primers } \\
\text { label }\end{array}$ & Sequence (5'-3') & Genes & $\begin{array}{c}\text { PCR } \\
\text { product }\end{array}$ & References \\
\hline FMD viruses & $\begin{array}{l}\text { FMDVF1 } \\
\text { FMDVR1 }\end{array}$ & $\begin{array}{l}\text { ctctctgttacacgctctcag } \\
\text { cgaacacagcgtgttcttgcc }\end{array}$ & Lpro & $430 \mathrm{bp}$ & $\begin{array}{l}\text { Islam et al., } \\
2016\end{array}$ \\
\hline \multicolumn{6}{|c|}{ Serotyping of FMD viruses: Upstream primers } \\
\hline SerotypeO & P38 & gtcgcctacctccttcaa & 1D & 402bp & \multirow{4}{*}{$\begin{array}{c}\text { Callens and } \\
\text { DeClercq, } \\
1997\end{array}$} \\
\hline SerotypeC & P40 & gtttctgcacttgacaacaca & 1D & 596bp & \\
\hline Serotype Asia 1 & P74:77 & $\operatorname{gacac}(\mathrm{c} / \mathrm{g}) \operatorname{ac}(\mathrm{t} / \mathrm{c} / \mathrm{a}) \mathrm{ca}(\mathrm{g} / \mathrm{a}) \operatorname{accgccg}$ & 1D & 292bp & \\
\hline Serotype A & P110 & $\begin{array}{c}\text { gt(g/ a/ t/ c)attgacct(g/ a/ t/ c)atgca } \\
(g / a / t / c) a c(g / a / t / c) c a c\end{array}$ & 1D & $732 \mathrm{bp}$ & \\
\hline \multicolumn{6}{|c|}{ Downstream primer } \\
\hline All serotypes & P33 & agdtgtaccagggtttggc & 2B & & \\
\hline \multicolumn{6}{|c|}{ Amplification of VP1 gene } \\
\hline $\begin{array}{l}\text { FMD viral } \\
\text { serotype } O\end{array}$ & $\begin{array}{l}A 1 F \\
A 2 R\end{array}$ & $\begin{array}{l}\text { accaatgtacagggatgggt } \\
\text { ttgcaccgtagttaaaggaa }\end{array}$ & 1D/ VP1 & 639bp & $\begin{array}{l}\text { Jamal et al., } \\
2012\end{array}$ \\
\hline
\end{tabular}


Table 2: Thermal profile used in uniplex and multiplex RT-PCR amplification/ detection of FMD viruses and their serotypes and sequencing of VP1 gene of viral serotype $O$

\begin{tabular}{|c|c|c|c|}
\hline \multirow[t]{2}{*}{ Points } & \multicolumn{3}{|c|}{ Description of RT-PCR } \\
\hline & $\begin{array}{c}\text { uRT-PCR } \\
\text { (FMD viruses) }\end{array}$ & $\begin{array}{c}\text { mRT-PCR } \\
\text { (FMD viral serotypes) }\end{array}$ & $\begin{array}{c}\text { URT-PCR } \\
\text { (VP1geneamplification) }\end{array}$ \\
\hline Reaction specificity & FMD viruses & FMD viral serotypes & FMD viral serotypeO \\
\hline Primers used & $\begin{array}{l}\text { FMDVF1 } \\
\text { FMDVR1 }\end{array}$ & $\begin{array}{c}\text { F-P38, P40, P74:77, } \\
\text { P110, R-P33 }\end{array}$ & $\mathrm{A} 1 \mathrm{~F}$ and $\mathrm{A} 2 \mathrm{R}$ \\
\hline Reversetranscription & $50{ }^{\circ} \mathrm{C}$ for $30 \mathrm{~min}$ & $45^{\circ} \mathrm{C}$ for $45 \mathrm{~min}$ & $50^{\circ} \mathrm{C}$ for $30 \mathrm{~min}$ \\
\hline Initial PCR activation & $95^{\circ} \mathrm{C}$ for $2 \mathrm{~min}$ & $95^{\circ} \mathrm{C}$ for $1 \mathrm{~min}$ & $94^{\circ} \mathrm{C}$ for $2 \mathrm{~min}$ \\
\hline Number of PCR cycles & 30 & 35 & 35 \\
\hline Denaturation & $94^{\circ} \mathrm{C}$ for $1 \mathrm{~min}$ & $95^{\circ} \mathrm{C}$ for $15 \mathrm{sec}$ & $94^{\circ} \mathrm{C}$ for $1 \mathrm{~min}$ \\
\hline Annealing & $55^{\circ} \mathrm{C}$ for $1 \mathrm{~min}$ & $600^{\circ} \mathrm{C}$ for $1 \mathrm{~min}$ & $47 \circ \mathrm{C}$ for $1 \mathrm{~min}$ \\
\hline Extension & $72^{\circ} \mathrm{C}$ for $2 \mathrm{~min}$ & - & $7^{\circ} \mathrm{C}$ for $2 \mathrm{~min}$ \\
\hline Final extension & $72^{\circ} \mathrm{C}$ for $7 \mathrm{~min}$ & $60^{\circ} \mathrm{C}$ for $6 \mathrm{~min}$ & $72^{\circ} \mathrm{C}$ for $7 \mathrm{~min}$ \\
\hline Hold at & $4 \circ \mathrm{C}$ & $4 \circ \mathrm{C}$ & $4 \circ \mathrm{C}$ \\
\hline
\end{tabular}

\section{Amplification of VP1 gene and sequencing}

Viral RNA extracted from the oral lesion of infected cattle (Jamal et al., 2012) was used in RT-PCR amplification of the fragment of VP1 gene (Table 1 and 2). The RT-PCR amplicons was gel-purified, sequenced from AIT biotech, Singapore and the sequences data were analysed to evaluate the extent of mutation and phylogenetic analysis. Sequence editing and alignment were carried out using the "Lasergene" software package (Modules-Edit Seq and MegAlign; DNASTAR Inc., USA).

\section{Sequence and phylogenetic analysis}

The CDNA of 1D and VP1 genes (639 bp) of FMD viral serotype O was used in analysis. All positions containing gaps and missing data were eliminated; a total of 485 nucleic acid bases remained in the final dataset for translational and phylogenetic analysis. The sequence information was used in Neighbour-J oining tree with kimura2 parameter (MEGA6, Tamura et al., 2013) to construct the phylogenetic tree and to know the topotype of the viruses. The robustness of the tree topology was assessed with 1,000 bootstrap replicates as implemented in the program.

\section{Results and Discussion}

\section{Clinical investigation}

FMD is characterized by fever and vesicular eruption in the mouth, nose, muzzle, foot, teats and other hairless soft areas of the body (Islam et al., 2016; Mannan et al., 2009). It is extremely fatal in calves, caused severe depression (Fig. 1a) and fatality. 
Both in young and adult dead cattle the diseasehas been called "tiger heart disease" (Gleeson et al., 2003; Islam et al., 2017b). The acutely infected cattle ( $n=25)$ showed excessive foamy salivation (Fig. 1b), erosions and ulceration in and around the mouth (Fig. 1c) and between hooves (Fig. 1d). During seven days observation, eight cattle appeared to be infected with FMD. Before blisters and ulcers appeared in the oral cavity a rise of temperature (1010F - 103F) was noted in all infected cattle. The highest temperature recorded was 105아 during the infective phase and sample from oral lesions were collected for viral RNA and RT-PCR detection of FMD virus (Table 3). The young calves had milder oral and pedal lesions, appeared dull, reluctant to move or stand, had inappetence, and died 2 - 3 days later. Adult cattle showed frothy salivation, lameness, inappetence and progressive weight loss. The infected cattle in all the farms showed pedal lesions and foot "flicking", a tucked up stance and reluctance to stand or walk. Thorough necropsy and histopathological investigation were carried out onto the dead calves $(n=3)$ and adult cattle $(n=2)$ to find out the reason of death.

Table 3: Rectal temperature profile in infected dairy cattle of Sujanagar Upazilla, Pabna district, Bangladesh. Cattle No. 5 and 8 not infected during the investigation period

\begin{tabular}{|c|c|c|c|c|c|c|c|c|c|c|}
\hline \multirow{2}{*}{$\begin{array}{c}\text { Days of } \\
\text { observation }\end{array}$} & \multicolumn{10}{|c|}{ Cattle number } \\
\hline & la & $2 b$ & $3 c$ & $4 d$ & 5 & 6 & 7 & 8 & 9 & 10 \\
\hline 0 & 999F & $100 \% F$ & 103ㅇF & $100 \% F$ & 999F & $98 \% F$ & $104 \% F$ & 999F & 98 아 & 99ㅇF \\
\hline 1 & 105 F $F$ & $1049 F$ & $104 \% F$ & 99ㅇF & 98ㅇF & 99아 & 103ㅇF & 101ㅇF & 99ㅇF & $1009 F$ \\
\hline 2 & $104 \% \mathrm{~F}$ & 103ㅇF & $1020 \mathrm{~F}$ & $1009 \mathrm{~F}$ & 999F & 100 ㅇ F & 103F & 100 ㅇ F & $1009 \mathrm{~F}$ & $104 \% \mathrm{~F}$ \\
\hline 3 & Dead & 103 ㅇF & $1020 \mathrm{~F}$ & $1040 F$ & 99아 & 99ㅇF & 101 F $F$ & 999F & 100 ㅇF & $104 \mathrm{~F}^{\circ}$ \\
\hline 4 & - & Dead & $100 \% \mathrm{~F}$ & Dead & 98ㅇF & 105 ㅇF & $1020 \mathrm{~F}$ & 99ㅇF & 99ㅇF & $102^{\circ} \mathrm{F}$ \\
\hline 5 & - & - & 99아 & - & 999F & 104\%F & Dead & $100 \% \mathrm{~F}$ & 99아 & 103ㅇF \\
\hline 6 & - & - & $1009 F$ & - & 99아 & $102^{\circ} \mathrm{F}$ & - & 99ㅇF & 105 ㅇF & $100^{\circ} \mathrm{F}$ \\
\hline 7 & - & - & 99아 & - & $100 \% \mathrm{~F}$ & 102 F $F$ & - & $100 \% F$ & 103ㅇF & $100 \%$ \\
\hline
\end{tabular}

$a=$ Threemonths old calf; $b, c$ and $d=$ cattlewere premature, cattle 5 to 10 were matured

\section{Necropsy of dead cattle}

At necropsy foamy saliva around mouth and nose was al so seen. The ulceration in the gum and tongue (Fig. 1c) was dominant and severe in adult cattle. Ulceration was al so seen onto the lips, cheeks, tongue and teats. The tongue papillae were inflamed, necrosed and disorganized. Ulceration was seen in the inter digital space, bulb of the heel and along the coronary band. There was erosion and ulceration in the rumen papillae of the adult cattle. The udder tissue of an infected cow appeared irregularly fibrosed and consolidated. The lungs of infected cattle were congested and consolidated. Characteristics white striping in the healthy pink muscle popularly known as "tiger heart disease" was seen in the young and adult cattle. Death of 
infected calves and adult cattle (Mannan et al., 2009; OIE, 2008) may be due to necrosis of cardiac muscle and cardiac failure.

\section{Histopathological changes}

Heart, lungs, liver, kidney, spleen, tongue and ulcerative areas of oral and pedal tissues showed prominent lesions. Most striking lesions seen were in the heart muscle and lungs. There was hyal inization and necrosis of cardiac muscle fibre in calves and adults and the necrosed muscle fibre were infiltrated with mononuclear cells (Fig. 2a). Focal aggregations of mononuclear cells were scanty in the heart muscle of infected calves. The lungs from infected calves and cows showed widespread interstitial pneumonia. The bronchioles of infected calves were distended and containing reactive cells. Mononuclear cellular infiltration was seen in the thickened interlobular septae of lungs (Fig. 2b) and in the interstitium. There was congestion and haemorrhage in the lungs, liver, kidney and spleen. The tongue of infected cow showed ulceration, erosion, necrosis and dissolution of surface epithelial layers (Fig. 2c). The interdigital skin showed ulceration and necrosis, the keratinized layer was sloughed off. The interdigital skin following seven days of infection showed regeneration of keratinized layer with minimal lymphocytic and neutrophilic infiltration.

Foot-and-mouth disease under natural exposure caused vesicular and ulcerative lesions in oral and pedal tissues. Numerous researchers have investigated the histopathological changes of tissues following infection with FMD. The primary site of infection and replication of FMD is in the mucosa of the pharynx. The virus may also enter through skin lesions or the alimentary tract. Once distributed throughout the lymphatic system, the virus replicates in the epithelium of the mouth, muzzle, teats, feet, and areas of damaged skin (Alexandersen et al., 2003; Alexandersen and Mowat, 2005). Vesides then develop at the organs and rupture within $24-48 \mathrm{hr}$. More than $50 \%$ of ruminants that recover from illness and those that are vaccinated and have been exposed to virus can carry virus particles in the pharyngeal region up to 3.5 years in cattle, 9 months in sheep, and $>5$ years in African buffalo (Arzt et al., 2011).

Recent data indicate that after initial replication of the viruses in pharynx, skin or intestine, the virus enters into the bloodstream through regional lymph nodes. The greater part of the viral amplification occurs within the stratified squamous epithelia of the skin (including the feet and mammary gland) and mouth (induding the tongue), or in the myocardium of young animals. In this study predominant lesion seen was in the lungs, heart, oral mucosa and skin at inter digital space. There was interstitial pneumonia both in young and adult cattle, the bronchioles of infected and dead calves was distended and inter lobular septa of adult cattle was markedly thickened due to deposition of fibrin. Mononuclear cellular infiltration was seen in the thickened interlobular septa and in the interstitium. Pulmonary tissues are not the common sites of FMD viral infection and replication (Alexandersen et al., 2003) but the extended of respiratory lesions as seen in lungs could have contributed to fatality 
(Islam et al., 2017a). Historically, the infected cattle recovered through infection showed respiratory distress (dyspnoea) during hard work. The histopathologic changes seen in the interlobular septa of lungs and interstitium could have contributed to pulmonary dysfunction. The cardiac tissues of young and adult cattle showed focal necrosis and infiltration of mononuclear cells in necrotic tissues. The mortality of young calf and adult cow as seen following FMD could be due to cardiac and respiratory failure alone or in combination. The oral and pedal lesions as seen in infected and dead cattle were typical of FMD (Aftosa et al., 2015). The clinicopathological evidence of FMD was further confirmed by RT-PCR.
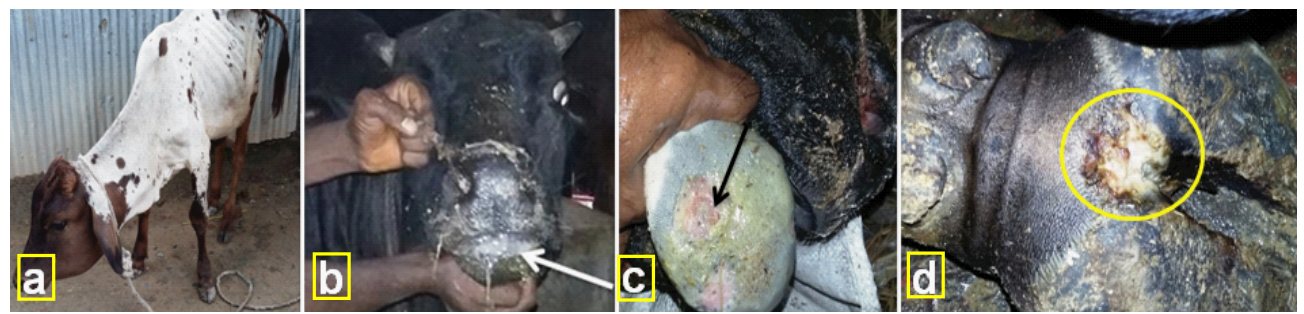

Fig. 1: Clinico-pathological investigation of FMD in cattle. An infected calf (a) showed depression and emaciation before death. Theinfected cow showed profuse salivation ( $b$, arrow) and ulceration on tongue (c, arrow). Sore leg ( $d$, circled) was commonly seen in adult cattle with FMD.

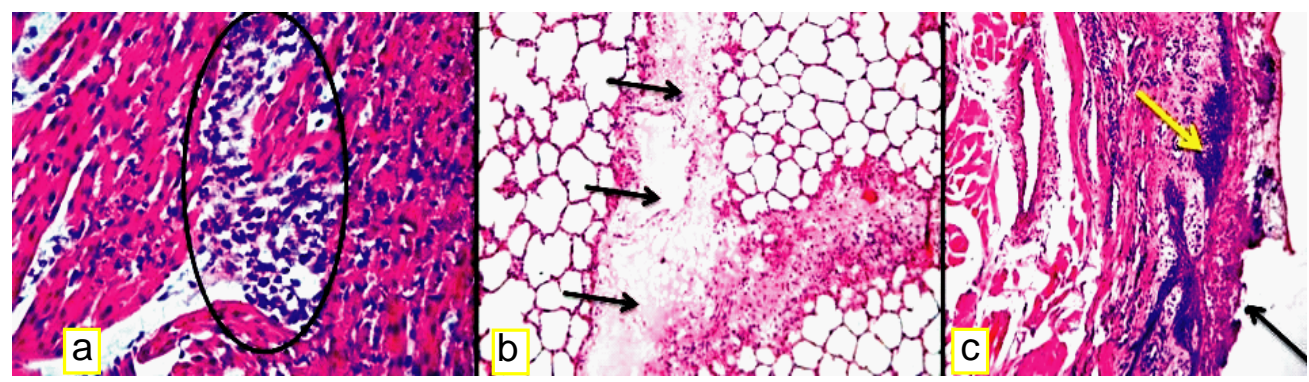

Fig. 2: Histopathology of tissues from infected and dead cattle $(H \& E)$. The myocardial lesions of infected and dead cattle were characterized by focal necrosis and the necrotic areas were infiltrated with mononuclear cells (a, circle, 40x). The interlobular septa of lungs appeared thicker and there was deposition of fibrins (b, arrow, 10x). The mucosa of infected tongue was severely inflamed, sloughed off (c, black arrow) and infiltrated with mononuclear cells (c, yellow arrow, 10x).

\section{RT-PCR detection of viral serotypes}

Extracted viral RNA used in uniplex RT-PCR successfully detected FMD viruses (Fig. 3a). Results of multiplex RT-PCR with representative samples generated 292 bp and 402 bp amplicons specific for the FMD viral serotypes "Asial" and " $O$ " respectively (Fig. 3b). The FMD viral serotypes "Asial" and "O" were identified among cattle at Sujanagar, Chatmahar, Isshardi and Sadar Upazillas, Pabna district. Viral RNA from oral tissues appeared best to detect FMD viral serotypes from infected cases. 
In viraemic state, serum sample can be used as a source of viral RNA and detection of FMD viral serotypes in RT-PCR (Reid et al., 2003).

The demonstration of FMD viral nucleic acid in RT-PCR is mostly confirmatory. Positive serotyping is needed especially to design preventive and control strategies and hence positive samples from the repository were always used in RT-PCR protocol. The uniplex PCR was applied (Islam et al., 2016) in this study to detect FMD viruses in general from the extracted RNA obtained from the oral lesions of infected cattle. RT-PCR is the most sensitive protocol for the detection of FMDV in oropharyngeal samples of infected animals (Carol and Meyer, 1993 and Islam et al ., 2016). RT-PCR detection of FMD viruses is more sensitive than conventional ELISA (Rodriguez et al., 1994). We observed that the RT-PCR protocol is simple, rapid and efficient tool for the detection of FMDV from clinical samples. To identify FMD viral topotypes, sequencing of VP1 gene and phylogenetic analysis was carried out.

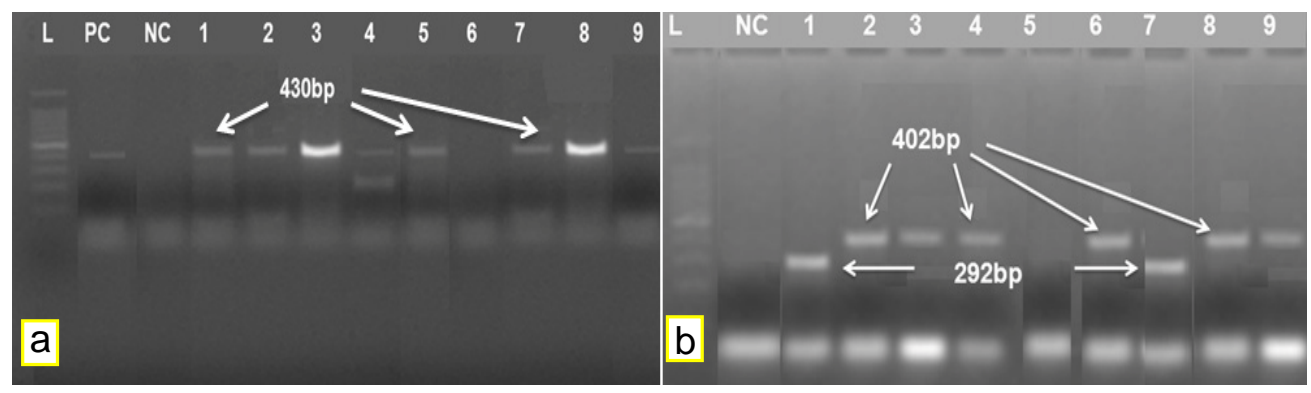

Fig. 3. Fig. 3: RT-PCR detection of FMD viruses (a) and its serotype (b) using uniplex (a) and multiplex (b) RT-PCR. Lane L is for 100 bp DN A ladder, NC is N egative control, PC positive control and Lane 1 to 9 arethe viral RNA collected from infected cattle. In positivecases 430bpamplicons (a) specific for FMD viruses was generated. Results of multiplex RT-PCR showed that the cattle of Pabna Sadar Upazilla were infected with FMD viral serotype Asia 1 (b, Lane 1 and 7, 292 bp). Cattle of Sujanagar, Chatmahar and Isshardi Upazilla were infected with FMD viral Serotype “O” (b, Lane 2, 3 4, 6, 8 and 9, 402 bp).

\section{Sequence and phylogenetic analysis}

Results of translational analysis revealed three point mutations in the fragment of VP1 gene studied. Out of 163 amino acid residues studied in the fragment of VP1 gene of FMD viral serotype "O"; three mutations was seen to affect amino adid position. Amino acid positions in 24 (Valine), 43 (Threonine) and 155 (Alanine) of VP1 gene was affected and replaced by Alanine, Alanine and Valine respectively. The percentage identity in the sequence of VP1 gene of FMD viral Serotype "O" was 97.5\% to $100 \%$. The Neighbour-Joining tree constructed by using VP1 gene sequence and MEGA6 programme showed that the FMD viral Serotype "O" belonged to ME-SA topotype (Fig. 4). Similar observation was also reported by Loth et al. (2011) and Hossen et al. (2014). However, effect of this mutation on the virulence of FMD virus was not evaluated. 


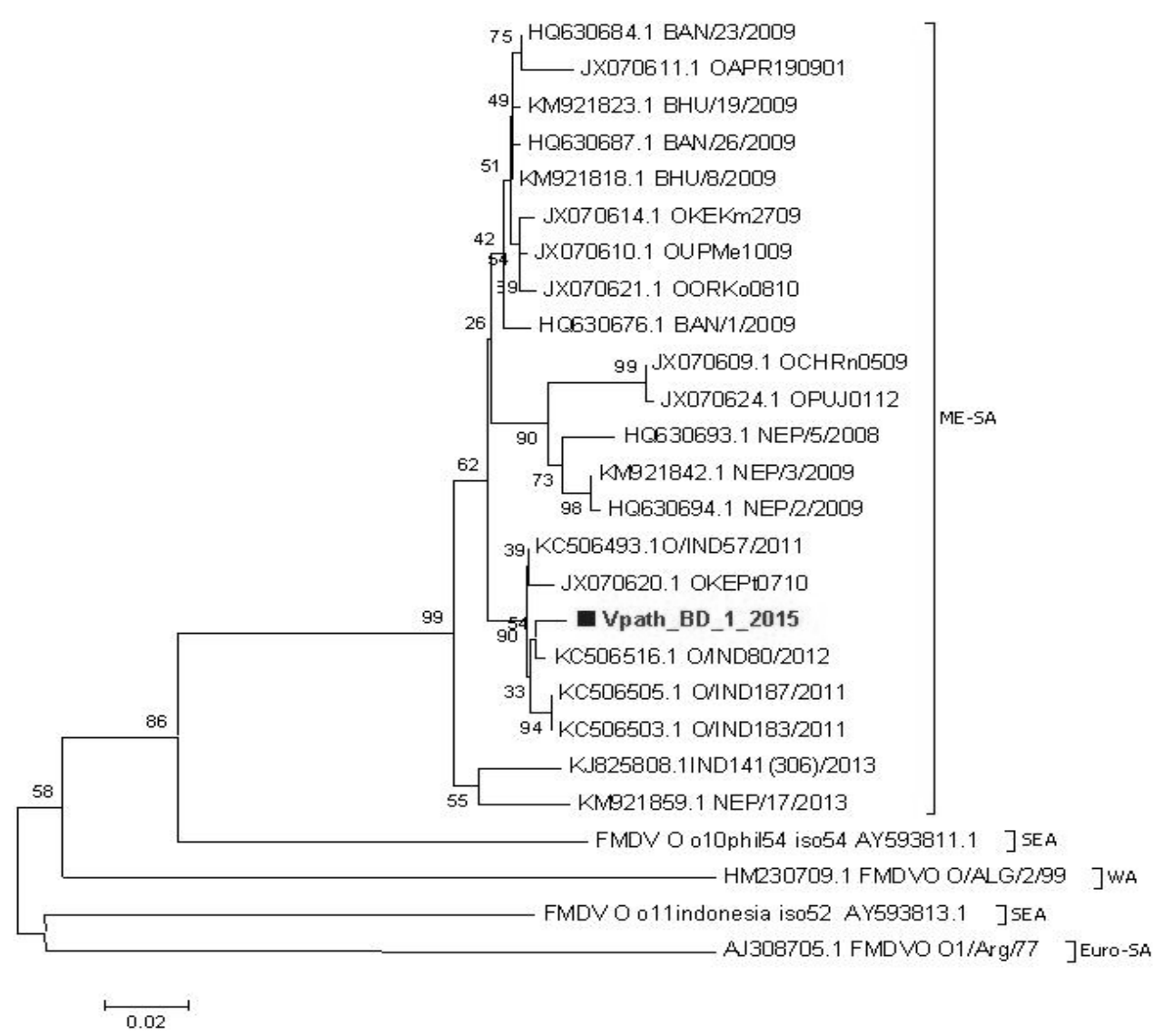

Fig. 4: Neighbour-Joining tree (1000 bootstrap) showing the relationships between sequences of VP1 gene of FMD viral Serotype "O". Results of this study showed that the FMD viral Serotype "O" studied belonged to ME-SA topotype

Full length sequencing of VP1 gene and sequence analysis revealed the degree of mutation and possible effect of this mutation onto antigenic variation. Three important mutations (24, 43 and 155) at VP1 gene was seen and could have contributed antigenic variation. The RT-PCR protocols adapted conferred faster results and enabled us to identify quickly the circulating FMD viral serotype(s) and topotype. The RT-PCR protocol can handle more samples in a single assay and can be a valuable tool to complement the routine diagnosis of viral serotypes/ topotypes from field outbreaks and designing preventive strategies.

\section{Acknowledgement}

Thanks are due to the SPGR, PIU/Bangladesh Agricultural Research Council, Farmgate, NATP-Phase-1, Dhaka, Bangladesh for financial support. 


\section{References}

Aftosa F 2015: Foot M outh Disease. The center for food security and public health. College of Veterinary Medicine, lowa State University, Ames lowa 50011, USA pp. 1-9.

Alamdari M, Eyed AG, Malahat A, Reyhaneh ST 2006: Detection of foot and mouth disease virus and identification of serotypes in East Azerbaijan province of Iran.V eterinarski A rhiv 76 413-419.

Alexandersen S, Mowat N 2005: Foot and Mouth Disease: Host Range and Pathogenesis. Current Topics in M icrobiology and Immunology 288 9-42.

Alexandersen S, Zhang Z, Donaldson AI and Garland AJ 2003: The pathogenesis and diagnosis of foot-and-mouth disease. Journal of Comparative Pathology 129 1-36.

APHIS 2007: Foot and mouth disease available at http//www.aphis.usda.gov/ publications/ animal health/ .

Arzt J, Baxt B, Grubman MJ, Jackson T, Juleff N, Rhyan J, Rieder E, Waters R, Rodriguez LL 2011: The pathogenesis of foot-and-mouth disease II: viral pathways in swine, small ruminants, and wildlife; myotropism, chronic syndromes, and molecular virushost interactions. Transboundary and E merging D iseases 58 305-326.

Bao HF, Li D, Guo JH, Lu ZJ, Chen YL, Liu ZX, Liu XT, Xie QG 2008: A highly sensitive and specific multiplex RT-PCR to detect foot and mouth disease virus in tissue and food samples. A rchives of $V$ irol ogy 153 205-209.

Brown CC, Piccone ME, Mason PW, McKenna TS, Grubman MJ 1996: Pathogenesis of wild-type and leaderless foot-and-mouth disease virus in cattle. Journal of Virology 70 5638-5641.

Brown F 2003: The history of research in foot and mouth disease. V irus R esearch 91 3-7.

Callens M, De Clercq K 1997: Differentiation of the seven serotypes of foot and mouth disease virus by reverse transcriptase polymerase chain reaction. Journal of $\mathrm{V}$ irol ogical M ethods 67 35-44.

Carol H, Mayer RF 1993: The detection of foot and mouth disease virus in oesophageal pharyngeal samples by a polymerase chain reaction technique. Journal of $V$ irological M ethods 43 1-6.

Chowdhury S, Rahman MZH, Rahman MF, Rahman MB, Rahman MM 1996: Strains of foot and mouth disease virus in different districts of Bangladesh. A sian-A ustralian Journal of A nimal Science 9 1-9.

Freiberg B, Rahman MM, Marquardt O 1999: Genetical and immunological analysis of recent $A$ sian type $A$ and $O$ foot-and-mouth disease virus isolates. Virus $G$ enes 19 167-182.

Gleeson LJ, Bauer K, Aidaros HA 2003: A review of the status of FMD in South East Asia and approach to control and eradication. Scientific and Technical Review of the Office International des Epizooties 21 465-475. 
Gomes L, Ramalho AK, Augo-De-Mello P 1997: Infectivity assays of foot and mouth disease virus: contact transmission between cattle and buffalo (Bubalusbubalis) in the early stage of infection. V eterinary Record 140 43-47.

Hossen ML, Ahmed S, Khan MFR, Rahman MT, Saha S, Nazir KHMNH, Rahman M., Islam MA, Rahman MB 2014: Typing of Foot and M outh Disease Virus Circulating in Bangladesh by Reverse Transcription Polymerase Chain Reaction. Journal of Veterinary A dvances 4 778-785.

Islam MR 2011: Regional study on economic impact of trans-boundary animal diseases. Country Status: Bangladesh. SAARC Agriculture Centre, Dhaka.

Islam MS, Ruba T, Habib MA, Rima UK, Hossain MZ, Saha PC, Das PM, Khan MAHNA 2016: Sequencing and Translational Analysis Revealed Huge Mutation in the NTerminus End of Leader Proteinase (Lpro) Gene of Foot and Mouth Disease Viruses Isolated From Cattle in Bangladesh. IOSR -Journal of A griculture and V eterinary Science 9 24-30.

Islam MS, Habib MA, Islam MR, Mahmud MS, Saha PC, Ruba T, Priya Mohan Das PM, Khan MAH 2017a: Clinicopathological investigation of foot and mouth disease and serotype identification of the viruses in cattle of Bangladesh. Immunology and Infectious D iseases 5 16-23.

Islam MS, Habib MA, Saha PC, Das PM, Khan MAHNA 2017b: Distribution of foot and mouth disease virus serotypes in cattle of Bangladesh. SAARC Journal of A griculture $1533-42$.

Jamal SM, Ferrari G, Hussain M, Nawroz AH, Aslami AA, Khan E, Murvatulloev S, Ahmed S, Belsham GJ 2012: Detection and genetic characterization of foot-and-mouth disease viruses in samples from clinically healthy animals in endemic settings. Transboundary and Emerging Diseases 59 429-440.

Knowles NJ, Samuel AR 2003: Molecular epidemiology of foot and mouth disease virus. V irus Research 91 65-80.

Lan CC, Tang R, Leong IUS, Love DR 2009: Quantitative real-time RT-PCR (qRT-PCR) of zebra fish transcripts: optimization of RNA extraction, quality control considerations, and data analysis. Cold Spring $\mathrm{H}$ arbor P rotocols 4 1-12.

Loth L, Osmani MG, Kalam MA, Chakraborty RK, Wadsworth J, Knowles NJ, Hammond JM, Benigno C 2011: Molecular characterization of foot-and-mouth disease virus: implications for disease control in Bangladesh. Transboundary Emerging Diseases 58 240-246.

Luna L 1968: M anual of histologic staining methods of the A rmed Forces Institute of Pathology. New York, USA.

Mannan MA, Siddique MP, Uddin MZ, Parvaz MM 2009: Prevalence of foot and mouth disease (FMD) in cattle at Meghnaupazila in Comilla in Bangladesh. Journal of Bangladesh A gricultural U niversity 7 317-319. 
MCVicar JW, Sutmoller P 1976: Growth of foot and mouth disease virus in upper respiratory tract of non-immunized, vaccinated, and recovered cattle after intranasal inoculation. Journal of Hygiene 76 467-481.

OIE 2008: Annual OIE/FAO FM D Reference Laboratory N etwork Report January - D ecember. Introduction to the OIE/ FAO FMD Reference Laboratory Network Report.http:/ / www.seafmd-rcu.oie.int/ index.php.

Pervin M, Faruque MH, Khanm SS, Chowdhury EH, Khan MAHNA 2011: Reverse transcription polymerase chain reaction (RT-PCR) for the detection and typing of foot and mouth disease virus in naturally infected cattle of Bangladesh. Bangladesh Journal of Progressive Science and T echnology IX 9-12.

Reid SM, Grierson SS, Ferris NP, Hutchings GH, Alexandersen S 2003: Evaluation of automated RT-PCR to accelerate the laboratory diagnosis of foot and mouth disease virus. Journal of Virological M ethods 107 129-139.

Rodriguez A, Nunez JI, Nolasco G, Ponz F, Sobrino F and De Blas C 1994: Direct PCR detection of foot-and mouth disease virus. Journal of V irological M ethods 47 345-349.

Rubina AA, Monzoor H, Amer BZA, Hamid I, Umer 2006: Epidemiological analyses of foot and mouth disease in Pakistan. International Journal of Agriculture and Biology 8 648-651.

Salt JS, Samuel AR, Kitching RP 1996: Antigenic analysis of type O foot and mouth disease virus in the persistently infected bovine. A rchives of Virology 141 1407-1421.

Shanmugam Y, Muthukrishnan M, Singanallur NB, Villuppanoor SA 2015: Phylogenetic analysis of the leader proteinase (Lpro) region of Indian foot and mouth disease serotype O isolates. V eterinarialtaliana 51 31-37.

Tamura K, Stecher G, Peterson D, Filipski A, Kumar S 2013: MEGA6: Molecular Evolutionary Genetics Analysis Version 6.0. M ol ecular Biology and Evolution 30 2725-2729. 